\title{
ソーダライムガラスにおける不純物の紫外線透過能 に対する影響
}

\section{藤田浩示* 高原良博}

九州工業大学大学院工学研究科機能システム創成工学専攻

J. Japan Inst. Metals, Vol. 71, No. 12 (2007), pp. 1071-1074

(C) 2007 The Japan Institute of Metals

\section{Influence of Impurities on Ultraviolet Ray Transmittance of the Soda-Lime Glass}

Koji Fujita* and Yoshihiro Takahara

Department of Applied Science for Integrated System Engineering, Graduate School of Engineering, Kyushu Institute of Technology, Kitakyushu 804-8550

Recently, research and development using ultraviolet rays is being conducted in the bioscience field. In such R\&D, expensive quartz glass is most often used as the ultraviolet transmitting material. The authors have been studying the use of inexpensive soda-lime glass as an alternative to quartz. In this study the authors investigated the effects of iron oxide and titanium oxide, which are found in raw materials, and crucible materials on the ultraviolet transmission properties of soda-lime glass. It was found that by reducing the amount of $\mathrm{Fe}_{2} \mathrm{O}_{3}$ and $\mathrm{TiO}_{2}$ contained in raw materials as impurities, it was possible for soda-lime glass to achieve high ultraviolet transmissivity. Reducing the amount of iron oxide turned out to be an especially effective way to improve ultraviolet transmissivity.

(Received June 22, 2007; Accepted September 3, 2007)

Keywords: ultraviolet transmission, soda-lime glass, ferric oxide, titanium oxide, non-bridged oxygen

\section{1. は じめに}

レーザー装置の部材や，分析用のチップ用部材，水銀灯部 材など種々の用途で紫外線透過材料が用いられている. 近 年, バイオ計測分野において紫外線を利用した分析が盛んに 行われるようになって来ており，これに伴って紫外線を透過 する材料に対する需要が著しく増大している1). バイオ計測 分野で特に良く使用されている紫外線波長は, $260 \mathrm{~nm}$ で, この波長を透過する材料として, 従来から, 石英や特殊ガラ スが用いられている.しかし，これらのガラス材料は非常に 高価であるため, 使い捨てられることが要求される医療や八 イスループットを要求されるバイオ計測分野では, 使用する ことが出来ず，プラスチック材料が主体となっている. プラ スチック材料は，紫外線透過率が低いことや有機溶剤に耐性 がないなど，使用用途が限定されてしまう。この様な背景か ら, 安価に大量生産可能な紫外線透過ガラスの開発が期待さ れている.

我々は, これまで, 安価でしかも有害な元素である $\mathrm{Pb}$, $\mathrm{Ba}, \mathrm{As}$ などを含なないソーダライムガラス組成を用いた紫 外線透過ガラスの可能性について検討を行ってきた. ソーダ ライムガラスにおいて紫外線を吸収する大きな要因は, 非架 橋酸素の存在である.これまで, ガラス組成そのものの研究

\footnotetext{
* 九州工業大学大学院生 (Graduate Student, Kyushu Institute of Technology)
}

やガラス中にフッ素をドーピングして, 紫外線吸収端を短波 長側にシフトさせる研究が盛んに行われている2-4).これに 対して, 我々はフッ素に比べてガラス中でより安定であり, 環境污染の点からも問題の少ない塩素の添加がフッ素と同様 に非架橋酸素の低減化に有効であることを明らかにした。し かしながら非架橋酸素の低減化だけでは十分な紫外線透過率 を得ることができなかった，その最大の原因としては，ガラ ス原料中のシリカに多く含まれる遷移金属の酸化物による紫 外線の吸収が考えられる.

そこで本研究では, ガラス中に含まれる不純物である遷移 金属酸化物, 特に多く含まれる酸化鉄と酸化チタ二ウムの $260 \mathrm{~nm}$ の紫外線吸収にあたえる影響について調べ，優先し て除去すべき不純物を特定し, その不純物除去により紫外線 透過率の改善が可能であるかを検討した，原料となるシリカ サンドは, 原料となる珪砂の産出地や精製方法により, 酸化 鉄, 酸化チタニウム含有量が異なる. 本研究により, われわ れが開発している紫外線透過ガラスに使用するシリカサンド の選定が容易になる. 酸化鉄, 酸化チタ二ウムについては, 紫外線領域の光を吸収することはすでに知られている しかしながら，バイオサイエンス分野で広く使用される 260 $\mathrm{nm}$ の波長に打ける影響について詳細に調べた研究はみあた らない，ガラスに含まれる酸化鉄は，II価と正価があり，均 質なソーダライムガラス中では, mass\%で, II価 : III価= $25: 75$ 前後であり, この割合を大きく変えると, 均質性や 泡の残存などの品質問題が生じるため, 大きく変えることは 
できない，紫外線の吸収は而価の酸化鉄により，生じること がわかっている5,6). 酸化還元をコントロールして，その量 を大幅に減らすことは，前述した理由で困難であるため，酸 化鉄全体量を減らすことを検討した。

\section{2. 実 験 方 法}

\section{1 基本組成と主原料シリカ}

シリケートガラス中で紫外線を吸収するのは，主にガラス 中の非架橋酸素と不純物として含まれる遷移金属酸化物であ る.このうち，今回の目標となる $260 \mathrm{~nm}$ 波長域を吸収する のは紫外線カット材料としても用いられる酸化鉄や酸化チタ ニウムといった不純物の遷移金属元素であると推定した.

それぞれの原料に含まれる不純物量が異なることから，高 純度の原料を用いやすい組成ほど有利となる。これらの観点 から，種々の組成につき，シリカ源に遷移金属などの不純物 の少ない高純度シリカである株式会社ニッチッ製のハイシリ カ SH-100M を用い，それ以外の原料には試薬特級品を用 いて調合した．ガラスの基本組成は，一般的なソーダライム 組成を選択した。その基本組成に，酸化鉄と酸化チタニウム を添加し，紫外線透過率の変化を測定した。 また同時に，坩 堝材質の違いによる紫外線透過能への影響も調べた.

\section{2 溶 解}

試料の溶解は，株式会社モトヤマ製のスーパーバーン炉を 用いて行った．坩堝には白金製と白金ロジウム合金製のもの を使用した。溶解条件としては， $1743 \mathrm{~K} て ゙ 2$ 時間溶解した 後, キャストして板状に成形した. その後, 直ちに徐冷炉に 入れて $1073 \mathrm{~K}$ で 1 時間保持した後, $100 \mathrm{~K} / \mathrm{h}$ の速度で室温 まで冷却した。板状にキャストした試料を切断, 研磨して $10 \mathrm{~mm}$ 角の立方体に加工した。作製した試料の組成は化学 分析と波長分散型蛍光 X 線分析法を用いて行った。本実験 で使用した微量成分以外の組成を Table 1 に示す。

\section{3 特性の測定}

作製した試料から厚さ $1 \mathrm{~mm}$ の板 $(10 \mathrm{~mm} \times 10 \mathrm{~mm})$ を切 り出し, 表面を光学研磨したものを紫外線透過率測定用試料 とした．表面および裏面での反射によるロスは，それぞれ約 4\%であった。測定には分光透過率測定装置 UV-3100PC, MPC-3100(島津製作所製)を用いた。

Table 1 Glass composition used in this study.

\begin{tabular}{lrr}
\hline & mass $\%$ & $\mathrm{~mol} \%$ \\
\hline $\mathrm{SiO}_{2}$ & 71.5 & 71.5 \\
$\mathrm{Al}_{2} \mathrm{O}_{3}$ & 2.4 & 1.4 \\
$\mathrm{MgO}$ & 3.4 & 5.1 \\
$\mathrm{CaO}$ & 5.0 & 5.4 \\
$\mathrm{Na} 2$ & 16.2 & 15.7 \\
$\mathrm{~K}_{2} \mathrm{O}$ & 1.5 & 1.0
\end{tabular}

\section{3. 結 果と考察}

\section{1 溶解温度および溶解ルツボ材質の影響}

白金ルツボのうち一部には，耐熱性や強度を高めるために 材質として純白金ではなく Pt : Rh=90：10の白金ロジウム 合金を用いている。しかし，ロジウム入りのルツボを用いて ガラスを溶かした場合，特に高温ではガラス中にロジウムが 溶け出し，短波長域で吸収を生じてガラスを黄色に着色する ことが知られている。これが紫外線透過率にどのような影響 を与えているか調査するため，ルツボの材質および溶解温度 を変えてソーダライムガラス(試薬により調合)を作製し，紫 外線透過率を測定した。得られた結果を Fig. 1 に示す. 260 $\mathrm{nm}$ 付近の透過率は溶解温度を $1723 \mathrm{~K}$ に下げることにより 大きく向上した．これは，溶解温度が高いと白金の溶出量が 増加するためだと考えられる.さらに，1823 K においては 白金と白金ロジウムではむしろ白金ロジウムの方が透過率が 高く，当初予想したロジウム溶出による紫外線透過率の低下 は認められなかった。この結果から，溶解用坩堝は，白金口 ジウム製が適していると考えられる.

\section{2 微量添加法による $\mathrm{Fe}_{2} \mathrm{O}_{3}, \mathrm{TiO}_{2}$ の吸光係数の測定}

すべての不純物を取り除いた高純度の原料は大幅なコスト アップを招く，そこで，取り除く必要のある不純物を特定す るため, ソーダライムガラスの透過率に対する不純物の寄与 を調べた．原料中に含をれる量が多く，さらに紫外線透過率 に大きな影響を与えると考えられるのは酸化鉄および酸化于 タンの二成分である，そこで，ソーダライムガラスに微量の 酸化鉄, 酸化チタンを添加して吸光係数を測定し, その変化 から各成分の吸光係数を求めた. 調合には，上述と同じ原料 および試薬の酸化鉄および酸化チタンを用いた。なお，作製 したガラスのうち不純物を添加しなかった試料の全鉄，酸化 チタンを定量した結果, $\mathrm{Fe}_{2} \mathrm{O}_{3}$ 換算での全酸化鉄量が 5 ppm, $\mathrm{TiO}_{2}$ が $6 \mathrm{ppm}$ であった。得られたサンプルの透過率 曲線を Fig. 2 に示す。また，酸化鉄，酸化チタンの含有量 とバイオ分野の計測で使用される代表的な紫外線波長 260

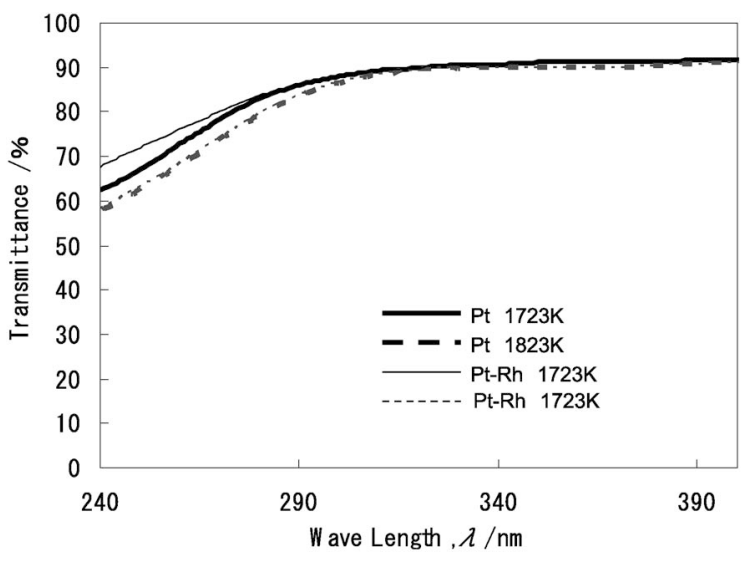

Fig. 1 Transmission spectra of soda-lime glasses fabricated with $\mathrm{Pt}$ and $\mathrm{Pt}-\mathrm{Rh}$ crucibles at different dissolving temperatures. 
$\mathrm{nm}$ における吸光係数の関係を Fig. 3 に示す. なお，反射率 の影響は $360 \mathrm{~nm}$ 付近の平坦部の透過率を $100 \%$ として規格 化することで除去した。なお，酸化鉄量 $100 \mathrm{ppm}$ と 200 ppm のサンプルは $260 \mathrm{~nm}$ の透過率が低すぎ, 精度が確保で きないと判断して計算から除外した.この図から算出した波 長 $260 \mathrm{~nm}$ に打けるモル吸光係数は，それぞれ酸化鉄 $0.0322 / \mathrm{mm} \cdot \mathrm{molppm}$ 抢よび酸化チタニウム $0.0018 / \mathrm{mm}$. molppm であった．酸化鉄のモル吸光係数は酸化チタンの 20 倍近くあり, 吸収の主要な原因を占めることが分かっ た.このことからソーダライムガラスの透過率はほぼ全鉄量 で決まり，母組成の影響はごく少ないことがわかった。

\section{3 ガラスを還元性にすることによる透過率の向上}

上述したようにソーダライムガラスの $260 \mathrm{~nm}$ 付近の吸収 のほとんどが酸化鉄に起因することがわかった。しかし，酸 化鉄のうち紫外域に強い吸収帯を持つのは 3 価の鉄イオン である5,6). そこで，原料を還元性にして酸化鉄の平衡を $\mathrm{FeO}$ 側に寄せることで透過率の向上を図ることにした，原 料の還元性は清澄剤として添加している硫酸ナトリウム, カーボンの比率を変更することで調整できるが，今回は硫酸

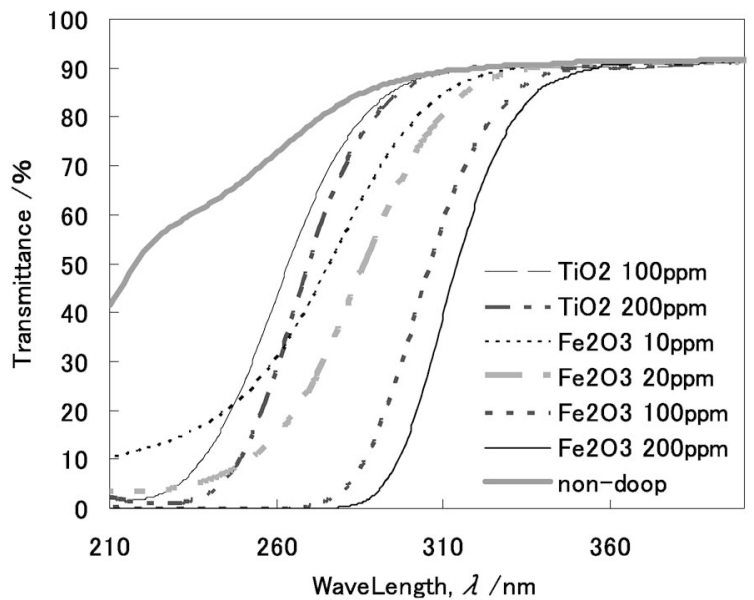

Fig. 2 Transmission spectra of soda-lime with different $\mathrm{Fe}_{2} \mathrm{O}_{3}$ and $\mathrm{TiO}_{2}$ compositions.

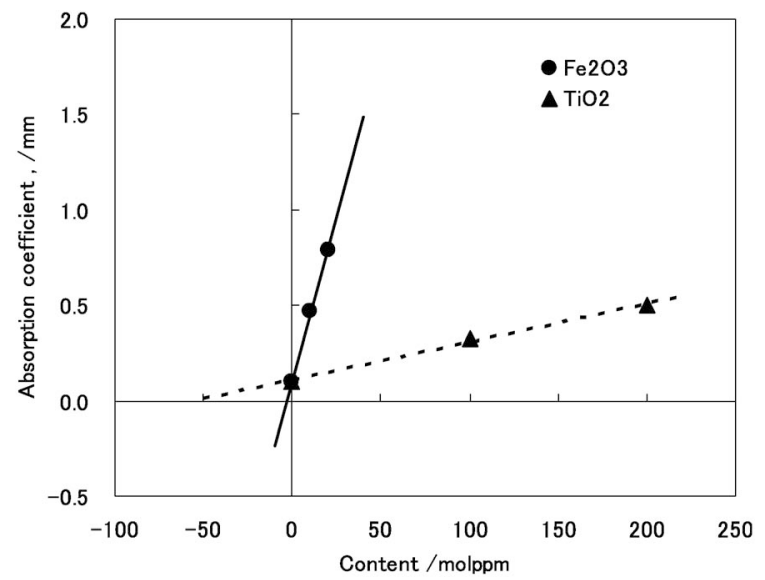

Fig. 3 Absorption coefficient at $260 \mathrm{~nm}$ as a function of $\mathrm{Fe}_{2} \mathrm{O}_{3}$ and $\mathrm{TiO}_{2}$ compositions.
ナトリウム量は一定とし, カーボン量を増やして還元性に寄 せることにした．白金ロジウムルツボを用いて $1723 \mathrm{~K}$ の温 度で，4 時間溶解してサンプル作製を行った。 ガラス原料 $400 \mathrm{~g}$ あたりのカーボン添加量と透過率との関係を Fig. 4 に 示す．測定值が複数ある物はサンプルを複数個作製したこと を示す．眓よりガラスが還元性になるほど透過率が向上する ことがわかる．最大で $80 \%$ 近い透過率を得ることが出来 た、また，ソーダライムガラス中の鉄量を減らすとサンプル に微細な泡が残存しやすくなるが，この実験においてカーボ ンの添加量を増やすことで泡品質の改善が認められた。しか し，標準のカーボン量の 3 倍程度で透過率が飽和すること がわかった。

\section{$3.4 \mathrm{Fe}_{2} \mathrm{O}_{3}$ の減少とガラスの泡について}

上述したようにソーダライム組成をベースとして，1 mm 厚での紫外線透過率が 80\%近いガラスを作製可能なことが 明らかになった。しかし, 一般的なソーダライムガラスの溶 融条件 $(1723 \mathrm{~K}$ で 4 時間) で溶解した場合に数十 $\mu \mathrm{m}$ 程度の 微細な泡が残留しやすく, 泡品質を改善するには溶融温度を $1773 \mathrm{~K} \sim 1823 \mathrm{~K}$ に上げる必要があったまなた，前述したよ うに, 高温の溶解では, 坩堝からの白金などの溶出により, 紫外線透過率がさがってしまう. 紫外線透過ガラス作製にお いては， $1723 \mathrm{~K}$ で溶解する方が好ましい。このため，この 実験では, $1723 \mathrm{~K}$ で溶解実験を行い. 泡を減少させる目的 で原料の還元度を変更した，試料作製にあたっては，鉄量お よびカーボン量を変化させて原料を調合した。この原料を $250 \mathrm{cc}$ の白金ロジウムルツボ $(\mathrm{Pt} 90$ : Rh10)に入れ， $1723 \mathrm{~K}$ に保温したカンタル炉中で $1 \sim 4$ 時間保持してから放冷，ル ツボから抜き取って泡数カウント用のサンプルとし, サンプ

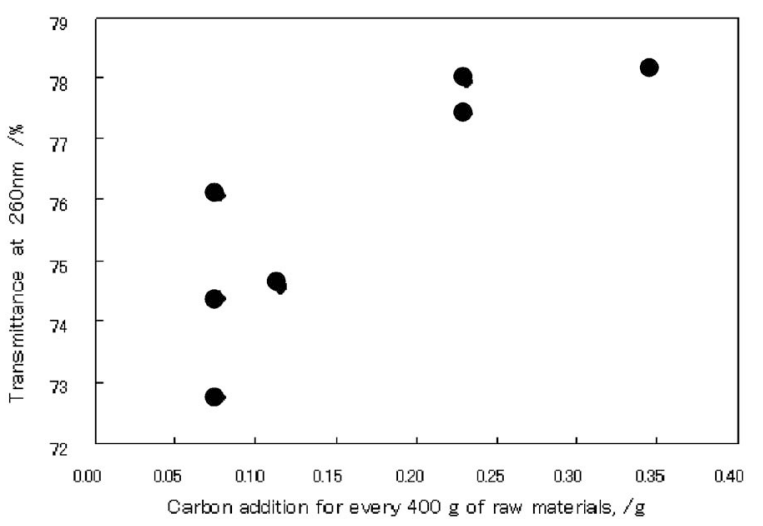

Fig. 4 Transmittance at $260 \mathrm{~nm}$ as a function of the carbon content. a function of carbon-addition.

Table 2 Relation between iron, carbon-addition, melting time and bubble-value in glass.

\begin{tabular}{ccrrr}
\hline $\mathrm{Fe}_{2} \mathrm{O}_{3} / \mathrm{ppm}$ & $\begin{array}{c}\text { carbon-addi- } \\
\text { tion/(\%) }\end{array}$ & \multicolumn{4}{c}{$\begin{array}{c}\text { Bubble-value, pieces/g in each melting time } \\
\text { ( h }\end{array}$} & $2 \mathrm{~h}$ & $4 \mathrm{~h}$ \\
\hline 2 & 0.06 & 13000 & 1200 & 59 \\
20 & 0.06 & 12000 & 410 & 0 \\
2 & 0.02 & 8300 & 950 & 120 \\
20 & 0.02 & 15000 & 1500 & 470 \\
\hline
\end{tabular}


ル中の泡を 40 倍の光学顕顕微鏡で観察し, $1 \mathrm{~g}$ あたりの泡 数を算出した。結果を Table 2 に示す. 酸化鉄無添加の場 合, 原料から入る酸化鉄のみであるので酸化鉄の組成は 2 ppm となる. 添加した方のサンプルの酸化鉄は $20 \mathrm{ppm}$ であ った.この結果から, ガラスを還元性にし, さらに鉄を添加 した試料の方が泡数が少なかった．このことから，紫外線透 過率が用途のとして求められる範囲に抢いて, 許容されるの であれば，酸化鉄量の多い方が泡の少ないガラスを得られる ことがわかった。 また，原料は鉄の含有量が少ないほど高価 である. 従って, 工業生産時には, 性能, 泡品質, 価格の面 から適切な酸化鉄量の原料を用いる必要がある。

\section{4. ま と め}

ソーダライムガラスについて，紫外線透過性能に及ぼす不 純物の影響を検討した結果, 以下の知見を得た。

(1) $260 \mathrm{~nm}$ 付近の吸収は母組成の紫外吸収端によるもの ではなく，鉄などの不純物に起因していることがわかった.
従って, 透過率を向上させるためには, 容器から溶出する不 純物を避けるため, できる限り低温で溶解を行う必要がある.

（2）カーボン添加などによりガラス原料を還元性にするこ とで鉄不純物による紫外吸収を減少させることができる.

（3）還元性原料の清澄性は鉄の存在下で向上する事が確認 された。

(4) 鉄不純物の量を $\mathrm{Fe}_{2} \mathrm{O}_{3}$ 換算でおよそ $2 \mathrm{ppm}$ 以下にす ることにより，1 $\mathrm{mm}$ 厚で波長 $260 \mathrm{~nm}$ に打ける透過率が 80\%近いガラス組成を得ることができた.

\section{文献}

1) M. Sakono, T. Maruyama, N. Kamiya and M. Goto: Biochem. Eng. J. 19 (2004) 217-220.

2) H. Hosone: OYO BUTURI 69(2000) 0415-0419.

3) N. Kamisugi, N. Kuzuu, Y. Ihara and T. Nakamura: Laser Eng. 26 (1998) 182-185.

4) Japanese Patent 64-79035.

5) Naruse: Glass Engineering, (Kyouritsusyuppan, 1958) p22-23

6) S. Sakka: Glass Handbook, (ASAKURA SYOTEN,1975) p836837. 